\title{
Development of Ischemia/Reperfusion Tolerance in the Rat Small Intestine An Epithelium-independent Event
}

\author{
David L. Osborne, Tak Yee Aw, Gediminas Cepinskas, and Peter R. Kvietys \\ With the technical assistance of Patsy R. Carter \\ Department of Physiology and Biophysics, Louisiana State University Medical Center-Shreveport, Shreveport, Louisiana 71130
}

\begin{abstract}
In stable organ systems, such as the heart and kidneys, an oxidant stress induces an increase in endogenous antioxidant systems resulting in an increased resistance of the tissue to a subsequent oxidant challenge. The development of this oxidant tolerance requires $1.5-6 \mathrm{~d}$. The aim of the present study was to determine whether oxidant tolerance can be induced in the small intestinal mucosa, a labile system whose epithelium turns over every 2-3 d. Ischemia/reperfusioninduced epithelial barrier dysfunction of the small intestinal mucosa was monitored in Sprague-Dawley rats whose intestines had been exposed to an ischemic insult 1,24 , or $72 \mathrm{~h}$ previously. At $24 \mathrm{~h}$, but not 1 or $72 \mathrm{~h}$ after the initial ischemic insult, the mucosa was more resistant to ischemia/ reperfusion-induced barrier dysfunction. The antioxidant status of the mucosa was enhanced at $24 \mathrm{~h}$, but not at 1 or $72 \mathrm{~h}$ after the initial ischemic insult. This adaptation appears to be specific for oxidants, since an initial ischemic insult imposed $24 \mathrm{~h}$ earlier also protected against $\mathrm{H}_{2} \mathrm{O}_{2}$-induced, but not acid- or ethanol-induced, barrier dysfunction. Further studies indicated that the increase in antioxidant status of the mucosa observed $24 \mathrm{~h}$ after the initial ischemic insult was a result of adaptational changes in the lamina propria, rather than the epithelium. In vitro studies with isolated epithelial cells also indicated that epithelial cells do not develop oxidant tolerance. We conclude that the development of oxidant tolerance in the small intestinal mucosa does not involve an active participation of the epithelial lining. ( $J$. Clin. Invest. 1994. 94:1910-1918.) Key words: glutathione peroxidase - catalase $\cdot$ superoxide dismutase $\cdot$ Caco-2 cells
\end{abstract}

\section{Introduction}

The reactive oxygen metabolites (ROMs) ${ }^{1}$, superoxide and/or hydrogen peroxide, are generated as a consequence of normal

Address correspondence to Peter R. Kvietys, Ph.D., Department of Physiology and Biophysics, Louisiana State University Medical Center, 1501 Kings Highway, P.O. Box 33932, Shreveport, LA 71130.

Received for publication 3 November 1993 and in revised form 25 July 1994.

1. Abbreviations used in this paper: CAT, catalase; GSHPX, glutathione peroxidase; I/R, ischemia/reperfusion; LDH, lactic dehydrogenase; ROM, reactive oxygen metabolite; SMA, superior mesenteric artery.

J. Clin. Invest.

(c) The American Society for Clinical Investigation, Inc. 0021-9738/94/11/1910/09 \$2.00

Volume 94, November 1994, 1910-1918 cellular aerobic metabolism $(1,2)$. Since these ROMs can participate in reactions which result in cytotoxicity, detoxification of these ROMs is a prerequisite for successful aerobic life. Mammalian cells contain SOD, which decomposes superoxide, and glutathione peroxidase and catalase, which decompose hydrogen peroxide. These enzymes constitute the major antioxidant systems responsible for preventing intracellular accumulation of cytotoxic levels of superoxide and hydrogen peroxide during normal aerobic metabolism (1). One pathologic event that is believed to disturb this oxidant/antioxidant balance is reperfusion of previously ischemic tissues $(2,3)$. Generally, it is believed that the burst of ROMs generated upon reperfusion overwhelms the detoxifying capacity of the enzymatic antioxidants and initiates a cascade of events that eventually leads to tissue injury.

Exogenous administration of SOD and/or catalase has been shown to offer protection against ischemia/reperfusion-induced tissue injury in a variety of organ systems (2-4). More recently, efforts have been directed toward enhancing the endogenous antioxidant status of tissues as a means of providing protection from ischemia/reperfusion (I/R) injury. The imposition of a mild oxidant stress in the heart (endotoxin) (5) or the kidney (ischemia/reperfusion) (6) results in the development of $I / R$ tolerance (i.e., the tissue becomes more resistant to a subsequent $I / R$ insult). The protective effect of the initial oxidant stress requires $1.5-6 \mathrm{~d}$ to develop, and is associated with enhanced activities of tissue antioxidant enzymes. The brain can also develop ischemic tolerance $1 \mathrm{~d}$ after mild ischemic episodes (7).

The organs in which I/R tolerance has been induced represent permanent or stable systems, where little or no cell proliferation occurs after full differentiation. There is no information available on whether a similar phenomenon exists in the more labile organ systems containing tissue with a high cell turnover rate (e.g., the gastrointestinal tract). Thus, the major objective of the present study was to assess whether I/R tolerance can be induced in the small intestine and to define the role of the epithelium in this phenomenon. The results of the present study indicate that $\mathrm{I} / \mathrm{R}$ tolerance can be induced in the small intestine, and that it is associated with an increase in mucosal antioxidant status. Furthermore, we provide evidence that the intestinal epithelial lining (labile tissue) does not play an active role in the development of $\mathrm{I} / \mathrm{R}$ tolerance in the intestine.

\section{Methods}

In vivo and in vitro approaches were used to systematically characterize the development of I/R tolerance in the small intestine. In vivo studies were designed to determine the time course of the development of I/R tolerance, and whether this phenomenon was associated with an enhanced antioxidant status of the mucosa (i.e., increased activity of superoxide dismutase, catalase, glutathione peroxidase, and its substrate gluta- 
thione). Furthermore, the in vivo model was also used to test the specificity of I/R tolerance for an oxidative stress and to assess whether the improved antioxidant status of the mucosa results from adaptational changes in the epithelial lining or the lamina propria. Finally, in vitro studies were undertaken to determine whether oxidant tolerance could be induced in epithelial cells in culture.

\section{In vivo studies}

Animal preparation. The experimental preparation used in this study is similar to that previously described (8-10). In brief, male SpragueDawley rats $(\sim 350 \mathrm{~g})$, previously fasted overnight, were anesthetized with 5-sec-butyl-5-ethyl-2-thiobarbituric acid (Inactin; Research Biochemicals International, Natick, MA; $120 \mathrm{mg} / \mathrm{kg}$, i.p.). A trachetomy was performed, and polyethylene tubing (PE-240) was inserted into the trachea to facilitate breathing. A femoral artery was cannulated for continuous monitoring of systemic arterial pressure. A femoral vein was cannulated for the periodic administration of fluid (5\% Ficoll; 70,000 mol wt) to maintain blood volume. A carotid artery was cannulated for obtaining blood samples. After an abdominal incision, a suture (silk 5.0) was passed around the superior mesenteric artery (SMA) and exteriorized through the laparotomy. A proximal segment $(10 \mathrm{~cm}$ in length) of jejunum ( $\sim 2 \mathrm{~cm}$ distal to the ligament of Treitz) was isolated and cannulated at both ends with soft polyethylene tubing. The proximal catheter was connected to a peristaltic pump (Minipuls; Gilson Medical Electromes, Inc., Middleton, WI) and the intestine perfused with normal saline $(\mathrm{pH}, \sim 6.0-6.5)$ at $1.0 \mathrm{ml} / \mathrm{min}$. The abdomen was irrigated with normal saline and covered with plastic wrap to prevent evaporative fluid loss. The renal blood vessels were ligated to prevent loss of the low molecular weight tracer used to quantitate intestinal mucosal integrity (see below). Body temperature was maintained at $36-37^{\circ} \mathrm{C}$ with a heating pad and lamp.

Quantitative assessment of mucosal epithelial integrity. After surgery, $100 \mu \mathrm{Ci}$ of ${ }^{51} \mathrm{Cr}$-labeled EDTA was administered as a bolus through the femoral venous catheter. Samples of intestinal perfusate were collected from the effluent jejunal cannula at 5-min intervals to monitor ${ }^{51} \mathrm{Cr}$-EDTA clearance. Once steady-state clearances were obtained $(60 \mathrm{~min})$, an additional 40 -min perfusion with normal saline ( $\mathrm{pH}, \sim 6.0-6.5$ ) served as a control. After the control period, the SMA was occluded by providing a standardized tension on the suture around the SMA. After a 20-min ischemic period, the tension on the suture was released, and the intestine was allowed to reperfuse for an additional $2 \mathrm{~h}$ (Fig. 1). Blood samples ( $300 \mu \mathrm{l})$ were taken during the control period, during the ischemic period, and every $\mathbf{4 0}$ min during the subsequent reperfusion period. At the end of the experiment, the animal was euthanized, and the segment of jejunum was removed and weighed. ${ }^{51} \mathrm{Cr}$ activity in the perfusate (effluent) and plasma samples were assessed using a gamma counter. The ${ }^{51} \mathrm{Cr}$-EDTA clearance was calculated using the following formula $(8-10)$ :

perfusate $(\mathrm{cpm} / \mathrm{ml}) \times$ perfusion rate $(\mathrm{ml} / \mathrm{min}) \times 100$

plasma $(\mathrm{cpm} / \mathrm{ml}) \times$ tissue weight $(\mathrm{g})$

${ }^{51} \mathrm{Cr}$-EDTA clearance (expressed as $\mathrm{ml} / \mathrm{min}$ per $100 \mathrm{~g}$ tissue weight) is a commonly used index of mucosal epithelial integrity (11).

Histological assessment of mucosal injury. The morphologic appearance of the jejunal mucosa was analyzed by light microscopy. Samples of jejunum were immersed in $2.0 \%$ paraformaldehyde $/ 2.5 \%$ glutaraldehyde in $0.1 \mathrm{M}$ phosphate buffer for $\geq 6 \mathrm{~h}$, dehydrated in graded ethanol up to $95 \%$ ethanol, and embedded in glycol methacrylate (JB-4; Polysciences Inc., Warrington, PA). The semithin sections $(2.5 \mu \mathrm{m})$ were stained with hematoxylin and eosin and were photographed with an Olympus BH-2 microscope. Mucosal epithelial injury was quantitated by assessing the percent of villi exhibiting a discontinuous epithelium (i.e., "breaks" in the epithelial barrier) $(8,9)$. Three animals per group were biopsied with $1,500-2,000$ villi being examined per group. To prevent observer bias, all mucosal samples were coded on collection and the codes were not made available to the investigator evaluating epithelial integrity.

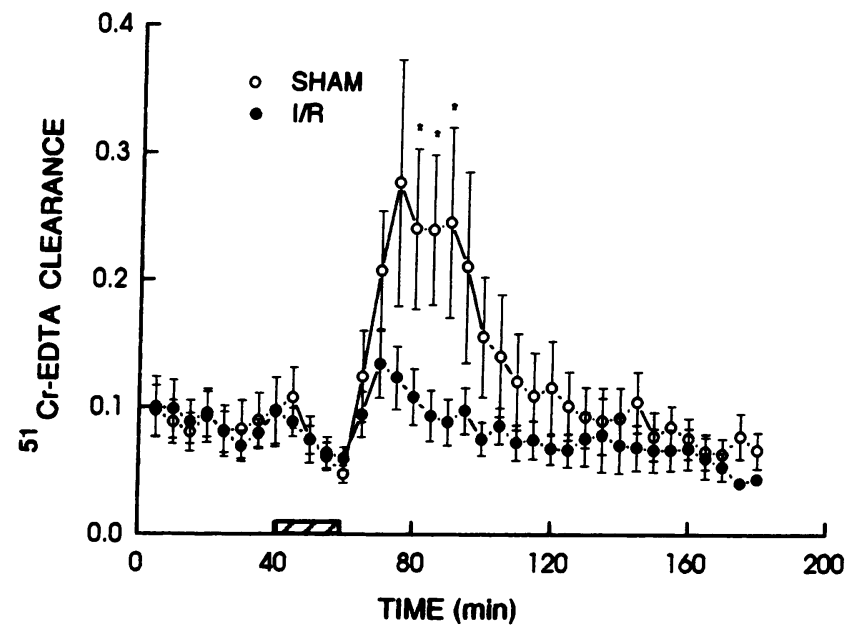

Figure 1. Effects of a 20-min period of intestinal ischemia (hatched bar) on ${ }^{51} \mathrm{Cr}$-EDTA clearance across the jejunal mucosal epithelium in animals whose SMA was occluded for $15 \mathrm{~min}(I / R)$ and animals whose SMA was merely massaged (SHAM) $24 \mathrm{~h}$ earlier. All values

$\left(\mathrm{ml} \cdot \mathrm{min}^{-1} \cdot 100 \mathrm{~g}^{-1}\right)$ are mean \pm SEM from nine animals in each group. As the omnibus ANOVA revealed significant interaction between time and treatment (sham vs I/R groups), posthoc comparisons (Duncan's test) for each time point were performed. ${ }^{*} P<0.05$ compared to corresponding time point in I/R group.

Separation of epithelium from the lamina propria. Epithelial cells were separated from the lamina propria using the method developed by Weiser (12). Jejunal segments were harvested, and the lumen was rinsed with $0.154 \mathrm{mM} \mathrm{NaCl}$ containing $1 \mathrm{mM}$ DTT and then filled with solution A ( $1.5 \mathrm{mM} \mathrm{KCl}, 96 \mathrm{mM} \mathrm{NaCl}, 27 \mathrm{mM} \mathrm{Na}$ citrate, $8 \mathrm{mM} \mathrm{KH}_{2} \mathrm{PO}_{4}$, and $5.6 \mathrm{mM} \mathrm{Na}_{2} \mathrm{PO}_{4}$ at $\mathrm{pH}$ 7.3). After $15 \mathrm{~min}$, solution $\mathrm{A}$ was removed and the segment was filled with solution $\mathrm{B}\left(\mathrm{Mg}^{2+} / \mathrm{Ca}^{2+}\right.$-free PBS, $1.5 \mathrm{mM}$ EDTA, and $0.5 \mathrm{mM}$ DTT ). After $8 \mathrm{~min}$, solution $B$ was collected and the segment rinsed and refilled with solution B. After $12 \mathrm{~min}$, the collection procedure was repeated and the segment refilled with solution B. After 37 additional min, the final collection was obtained. Histological examination of the mucosa indicated that the 8-min fraction contained villus tip cells, the 12-min fraction contained mid-villus cells, and the 37 -min fraction contained crypt cells.

Mucosal antioxidant status. Jejunal segments were removed to icecold saline for removal of contents and the segments opened along their longitudinal axis. Mucosa was scraped from the muscle layers and weighed. In some experiments, the epithelial cells were separated from the lamina propria (as described above), centrifuged at $900 \mathrm{~g}$ for $5 \mathrm{~min}$, and the supernatant was removed. The naked lamina propria was then scraped from the muscle layer. The scraped mucosa, epithelial cells, and scraped lamina propria were stored at $-70^{\circ} \mathrm{C}$ until they were analyzed for SOD, catalase (CAT), glutathione peroxidase (GSHPX) activities, or GSH content. For analysis, the tissues or cells were thawed and homogenized as a $10 \% \mathrm{wt} / \mathrm{vol}$ mixture in a $20-\mathrm{mM}$ phosphate buffer (pH 7.4), centrifuged at $8,000 \mathrm{~g}$ for $20 \mathrm{~min}$ at $4^{\circ} \mathrm{C}$ (RC-5B; Beckman Instruments, Inc., Fullerton, $\mathrm{CA}$ ). The resulting supernatant was analyzed for SOD, catalase, and GSHPX activities, and for GSH content.

SOD activity was analyzed by the method of Crapo (13), in which inhibition of the rate of reduction of cytochrome $\mathrm{C}$ by superoxide radicals is used as an indirect measurement of SOD activity. SOD activity measured in this assay represents total tissue SOD activity, and is expressed as $1 \mathrm{U}=\mathrm{SOD}$ activity required to inhibit cytochrome $\mathrm{C}$ reduction by $50 \%$. Catalase activity was determined by the method of Aebi (14), where the disappearance of hydrogen peroxide was monitored at $240 \mathrm{~nm}$ as a measure of catalase activity. $1 \mathrm{U}$ of catalase activity is defined as $1 \mu \mathrm{mol}$ of $\mathrm{H}_{2} \mathrm{O}_{2}$ degraded/minute per mg protein. GSHPX 

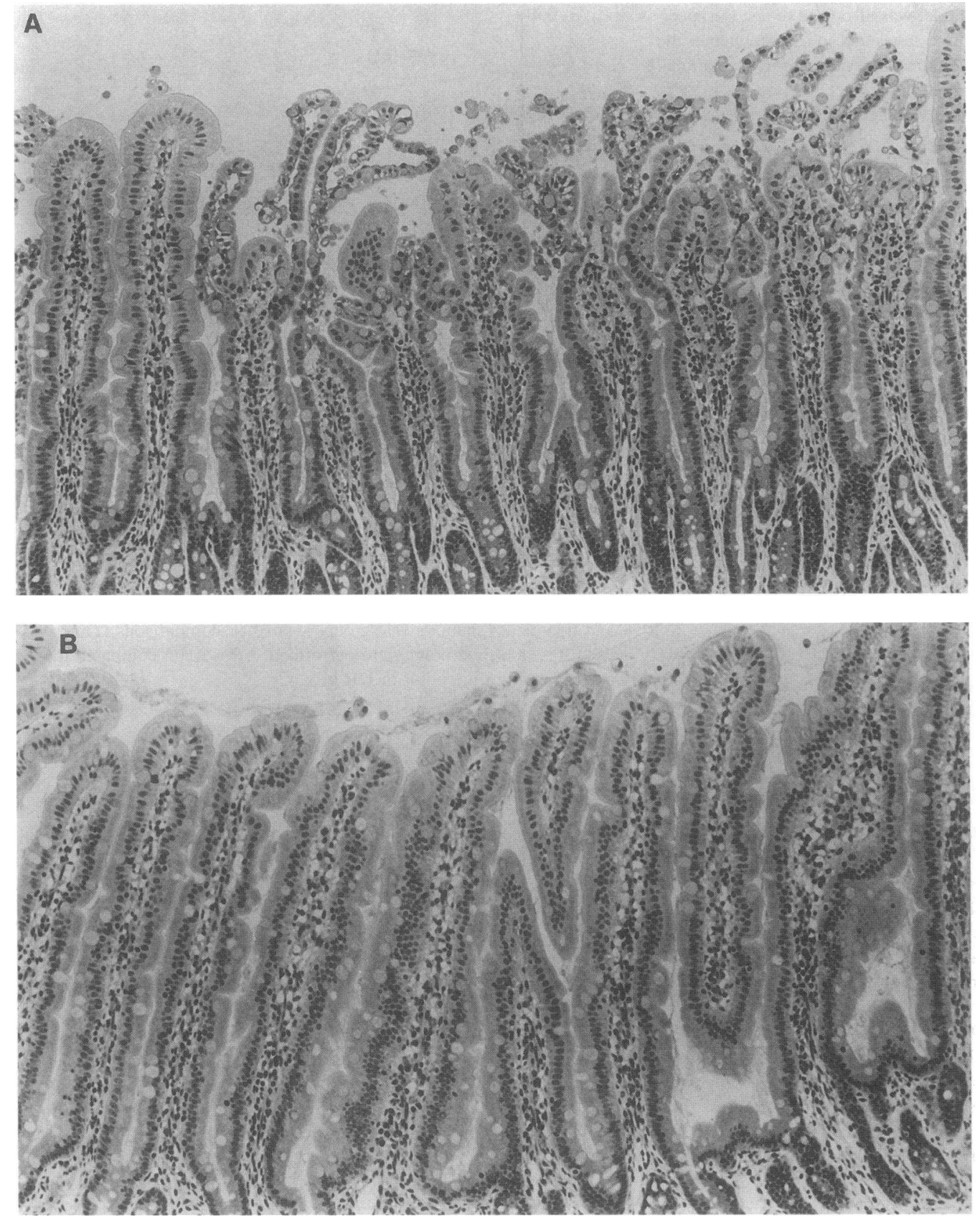

Figure 2. Rat jejunal mucosa after a 20-min period of intestinal ischemia (80-min time point in Fig. 1) from animals whose SMA was occluded for $15 \mathrm{~min}(B)$ and animals whose SMA was merely massaged (A) $24 \mathrm{~h}$ earlier. I/R injury was generally characterized by sheets of epithelium detaching from the lamina propria. The I/R group had $13.3 \pm 2.7 \%$ of their villi damaged by the second ischemic insult, whereas the sham group had $46.6 \pm 1.1 \%$ of their villi damaged.

activity was measured by the method of Tappel (15). This method measures the reduction of glutathione [oxidized] by spectrophotometrically following a coupled reaction involving the oxidation of NADPH where the disappearance of NADPH is monitored at $340 \mathrm{~nm}$. $1 \mathrm{U}$ of GSHPX activity is defined as $1 \mu \mathrm{mol}$ of NADPH converted to NADP/ min per mg protein. GSH content was measured by the method of Owens and Belcher (16), in which GSH content is determined spectrophotometrically following incubation of tissue lysates with 5,5'-dithiobis (2-nitrobenzoic acid) (DTNB) and measuring absorbance at 412 $\mathrm{nm}$. This method determines total tissue thiol content; however, HPLC analysis in our laboratory indicates that $>97 \%$ of the determined thiol content is GSH. Total tissue GSH content is expressed as micrograms per milligram of protein. All biochemical analyses were standardized per milligram of protein content, as determined by the method of Bradford (17) using gamma globulin as a standard.
Experimental protocols. The animals were anesthetized with Ethrane/Telazol ( $14 \mathrm{mg} / \mathrm{kg}$, i.m.) and, after a midline laparotomy, the SMA was isolated. In the experimental (I/R) group, the SMA was occluded for $15 \mathrm{~min}$ with a bulldog vascular clamp (Fire Science Tools, Inc., Foster City, CA). After the ischemic insult, the vascular clamp was removed, the laparotomy was closed with staples, and the animals were allowed to recover (water ad lib, no food). In the control (sham) group, the animals were treated in an identical manner to those in the I/R group, except that the SMA was gently massaged, not occluded. $24 \mathrm{~h}$ later, animals from each group were anesthetized with inactin and instrumented for monitoring I/R-induced changes in mucosal integrity using of ${ }^{51} \mathrm{Cr}$-EDTA clearance as described above. The second acute surgery was timed such that the induction of a 20-min period of SMA occlusion occurred $24 \mathrm{~h}$ after the initial 15-min occlusion or massaging of the SMA. The animals tolerated the surgery well and remained fairly 


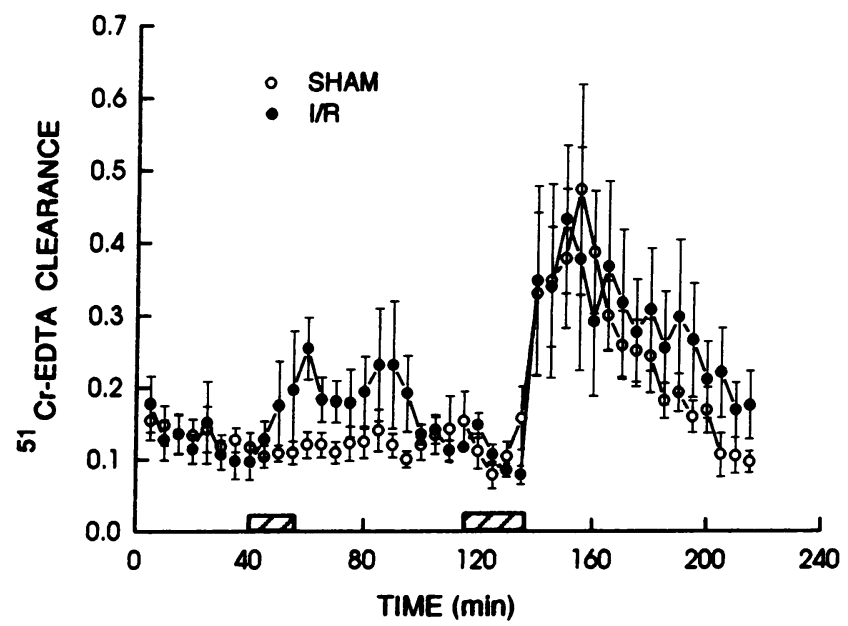

Figure 3. The effects of a 20-min period of intestinal ischemia (hatched bar) on ${ }^{51} \mathrm{Cr}$-EDTA clearance across the jejunal mucosal epithelium in animals whose SMA was occluded for $15 \mathrm{~min}(\mathrm{I} / \mathrm{R})$ and animals whose SMA was merely massaged (SHAM) $1 \mathrm{~h}$ earlier. All values $\left(\mathrm{ml} \cdot \mathrm{min}^{-1} \cdot 100 \mathrm{~g}^{-1}\right)$ are expressed as the mean \pm SEM from eight animals in each group.

stable throughout data collection. For example, mean systemic arterial pressure in the sham-operated animals was $108 \pm 3,115 \pm 10,102 \pm 9$, and $90 \pm 9 \mathrm{mmHg}$ at the $40-, 80-, 120-$, and 160 -min time points in Fig. 1 , respectively. In the animals exposed to I/R $24 \mathrm{~h}$ earlier, mean systemic arterial pressure was $102 \pm 12,111 \pm 12,100 \pm 13$, and $91 \pm 7 \mathrm{mmHg}$ at the 40-, 80-, 120-, and 160-min time points in Fig. 1, respectively.

The rat intestine is a labile organ system whose epithelium is completely replaced within $2-3 \mathrm{~d}(18)$. Thus, we assessed whether I/R tolerance can be demonstrated in the intestine $72 \mathrm{~h}$ after the initial I/R insult. The same protocol described above was used to impose the initial I/R insult, except that the animals were allowed to recover for $72 \mathrm{~h}$ (food and water ad lib for the first $48 \mathrm{~h}$, water ad lib and no food for the last $24 \mathrm{~h}$ ). Subsequently, the animals were instrumented for monitoring mucosal epithelial integrity using ${ }^{51} \mathrm{Cr}$-EDTA clearance during the second $I / R$ insult as described above.

Previous studies in the heart indicate that I/R tolerance can develop within minutes (19). Thus, we assessed whether I/R tolerance can be demonstrated in the intestine $1 \mathrm{~h}$ after the initial $\mathrm{I} / \mathrm{R}$ insult. In these experiments, rats were fasted for $24 \mathrm{~h}$ (water ad lib) and anesthetized with Inactin. The animals were instrumented for monitoring I/R-induced changes in mucosal integrity using ${ }^{51} \mathrm{Cr}$-EDTA clearance as described above. After an initial 40-min control period, the SMA was occluded by providing a standardized tension on the suture around the SMA. After a 15-min I/R period, the suture was released, and the intestine was reperfused for $1 \mathrm{~h}$. Subsequently, the SMA was occluded a second time by placing tension on the suture for $20 \mathrm{~min}$. After the second I/R insult, the intestine was allowed to reperfuse. As a control (sham), some animals were not exposed to the initial $I / R$ insult.

In another series of experiments, sham and I/R animals were prepared as described above for ${ }^{51} \mathrm{Cr}$-EDTA studies. Jejunal mucosa was harvested at 1,24 , or $72 \mathrm{~h}$ after the initial I/R insult for assessment of mucosal antioxidant status as described above.

The above experiments indicated that a previous I/R insult largely prevented the rise in ${ }^{51} \mathrm{Cr}$-EDTA clearance induced by a subsequent I/ $\mathrm{R}$ challenge imposed $24 \mathrm{~h}$ later. No protective effect was noted if the hiatus between I/R insults was 1 or $72 \mathrm{~h}$. Similarly, the antioxidant status of the mucosa was enhanced at $24 \mathrm{~h}$, but not at 1 or $72 \mathrm{~h}$, after the initial insult. Thus, subsequent experiments were designed to further characterize the I/R tolerance that was manifest at $24 \mathrm{~h}$ after the initial $\mathrm{I} / \mathrm{R}$ insult.

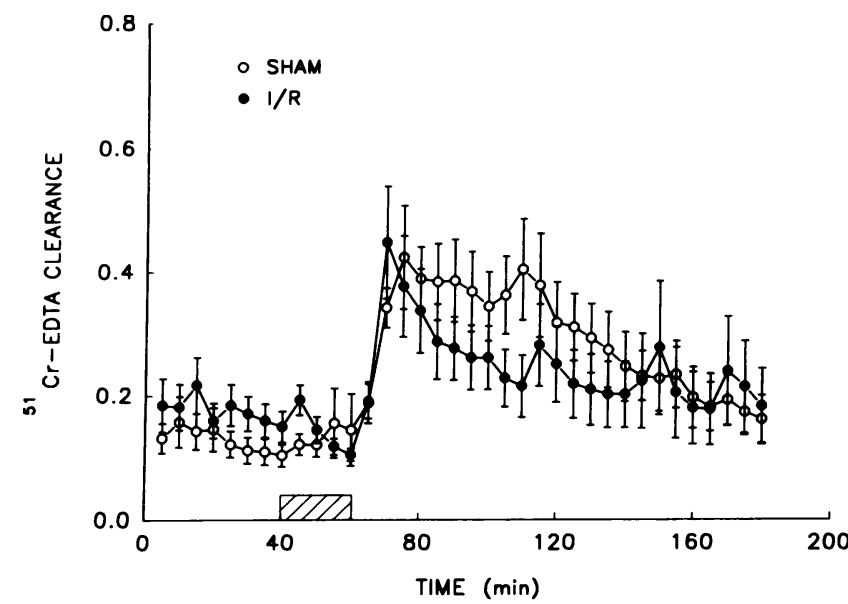

Figure 4. The effects of a 20-min period of intestinal ischemia (hatched bar) on ${ }^{51} \mathrm{Cr}$-EDTA clearance across the jejunal mucosal epithelium in animals whose SMA was occluded for $15 \mathrm{~min}(I / R)$ and animals whose SMA was merely massaged (SHAM) $72 \mathrm{~h}$ earlier. All values $\left(\mathrm{ml} \cdot \mathrm{min}^{-1} \cdot 100 \mathrm{~g}^{-1}\right)$ are expressed as the mean \pm SEM from eight animals in each group.

A group of I/R and sham-operated animals were prepared for histologic verification of the development of I/R tolerance $24 \mathrm{~h}$ after the initial I/R insult. Tissue samples were obtained $20 \mathrm{~min}$ after reperfusion (80-min time point in Fig. 1), and mucosal integrity was evaluated histologically.

In another series of experiments, we tested the specificity of this I/ $\mathrm{R}$ tolerance. Animals that had been exposed to intestinal ischemia 24 $\mathrm{h}$ earlier were instrumented for measurement of ${ }^{51} \mathrm{Cr}$-EDTA clearance as described above. However, instead of imposing a second $I / R$ insult, the lumen of the jejunum was perfused with either $\mathrm{H}_{2} \mathrm{O}_{2}(5 \mathrm{mM}), \mathrm{HCl}$ $(5 \mathrm{mM})$, or ethanol (15\%).

To assess whether the epithelial cells lining the villi played an active role in the development of $I / R$ tolerance, the following two series of experiments were performed. Sham and I/R animals were prepared, and $24 \mathrm{~h}$ after the initial insult, the epithelial cells were separated from the lamina propria as described above. Both the isolated epithelial cells and the lamina propria were biochemically evaluated for changes in their antioxidant status. In another group of sham and I/R animals, epithelial cells were harvested from the villus tips $24 \mathrm{~h}$ after the initial I/R insult, and their susceptibility to oxidant stress was evaluated. The isolated epithelial cells were exposed to $\mathrm{H}_{2} \mathrm{O}_{2}(5 \mathrm{mM})$ for $10-20 \mathrm{~min}$, and their viability was assessed by endogenous lactic dehydrogenase ( $\mathrm{LDH})$ release. LDH release was expressed as the percent of maximal LDH released from cells lysed with $0.05 \%$ Triton $\mathrm{X}-100$, as described by Bergmeyer et al. (20).

\section{In vitro studies}

Since the viability of rat enterocytes decreases within minutes after isolation from the villi (21), long-term (hours) experiments to study the development of oxidant tolerance were not feasible. Thus, we used the human carcinoma cell line, Caco-2 (American Type Culture Collection, Rockville, MD), to study this phenomenon. Caco-2 cells are malignant, not normal, cells, and they are colonic, not small intestinal, cells. Nonetheless, we chose to use this cell line because it has been well characterized, and it exhibits morphological (establishment of polarity, microvilli, etc.) and functional (brush-border enzymes, ionic transport, etc.) characteristics of mature small intestinal enterocytes (22).

Cell culture. The Caco- 2 cells were grown in high glucose DMEM (GIBCO Laboratories, Grand Island, NY) supplemented with 20\% FBS, $50 \mathrm{U} / \mathrm{ml}$ penicillin, and $50 \mu \mathrm{g} / \mathrm{ml}$ streptomycin. The cell cultures were 
Table I. Jejunal Mucosal Antioxidant Status 1, 24, and $72 \mathrm{~h}$ after an I/R Insult

\begin{tabular}{|c|c|c|c|c|c|c|}
\hline & \multicolumn{2}{|c|}{$1 \mathrm{~h}$} & \multicolumn{2}{|c|}{$24 \mathrm{~h}$} & \multicolumn{2}{|c|}{$72 \mathrm{~h}$} \\
\hline & SHAM & $I / R$ & SHAM & I/R & SHAM & I/R \\
\hline SOD & $5.0 \pm 0.1$ & $4.9 \pm 0.4$ & $4 . .9 \pm 0.4$ & $5.2 \pm 0.7$ & $5.2 \pm 0.1$ & $5.1 \pm 0.3$ \\
\hline CAT & $3.1 \pm 0.2$ & $3.1 \pm 0.2$ & $3.1 \pm 0.2$ & $4.1 \pm 0.2^{*}$ & $3.1 \pm 0.5$ & $3.4 \pm 0.4$ \\
\hline GSHPX & $38 \pm 2$ & $42 \pm 2$ & $44 \pm 2$ & $54 \pm 4 *$ & $38 \pm 2$ & $39 \pm 4$ \\
\hline GSH & $2.9 \pm 0.3$ & $2.9 \pm 0.2$ & $3.3 \pm 0.2$ & $5.0 \pm 0.9 *$ & $3.8 \pm 0.2$ & $6.7 \pm 0.7 *$ \\
\hline
\end{tabular}

$I / R$, animals whose superior mesenteric artery was occluded for $15 \mathrm{~min}$ at 1,24 , or $72 \mathrm{~h}$ before biopsy; SHAM, animals whose superior mesenteric artery was only massaged at 1,24 , or $72 \mathrm{~h}$ before biopsy. Enzyme activities are expressed in milliunits per milligram, while GSH content is expressed in micrograms per milligram of protein. Values represent mean $\pm S E M$ of assays on mucosal samples obtained from six to eight rats. $* P<0.05$ compared to SHAM. (Student's $t$ test).

maintained in a humidified atmosphere with $5 \% \mathrm{CO}_{2}$ at $37^{\circ} \mathrm{C}$, and were expanded by brief trypsinization $\left(0.25 \%\right.$ trypsin in $\mathrm{Ca}^{2+} / \mathrm{Mg}^{2+}$-free BSS containing $0.02 \%$ EDTA). The epithelial cells were seeded into collagen-coated (collagen IV; Sigma Chemical Co., St. Louis, MO) 48well plates, and were used in experiments at $7 \mathrm{~d}$ after confluence (8).

Experimental protocol. To assess whether oxidant tolerance could be induced in Caco- 2 cells, confluent monolayers were exposed to 0.4 $1.6 \mathrm{mM} \mathrm{H}_{2} \mathrm{O}_{2}$ for $1 \mathrm{~h}$. Subsequently, the monolayers were washed with HBSS, DME containing ${ }^{51} \mathrm{Cr}$ was added, and the cells were incubated at standard conditions for $24 \mathrm{~h}$. The monolayers were washed with HBSS to remove media containing ${ }^{51} \mathrm{Cr}$, and incubated with $\mathrm{H}_{2} \mathrm{O}_{2}(1.2-$ $7.2 \mathrm{mM})$ for $4 \mathrm{~h}$. Subsequently, an aliquot $(450 \mu \mathrm{l})$ of the supernatant $(500 \mu \mathrm{l})$ was obtained, and the remainder was aspirated. Then, $500 \mu \mathrm{l}$ of PBS was added to the wells, the monolayers were washed gently, and an aliquot $(450 \mu \mathrm{l})$ of the wash was obtained. Finally, $500 \mu \mathrm{l}$ of $2 \mathrm{~N} \mathrm{NaOH}$ was added to the wells to lyse the cells, and $2 \mathrm{~h}$ later a sample of the lysate was obtained. The ${ }^{51} \mathrm{Cr}$ activity of supernatant, wash, and lysate was determined with a gamma counter. Two indices of epithelial cell injury were calculated according to the following equations.

percent of ${ }^{51} \mathrm{Cr}$ release

supernatant $(\mathrm{cpm}) \times 100$

$=\overline{\text { supernatant }(\mathrm{cpm})+\text { wash }(\mathrm{cpm})+\text { lysate }(\mathrm{cpm})}$

Percent of ${ }^{51} \mathrm{Cr}$ release into the supernatant was taken as an index of epithelial cell lysis (23-25).

percent of cell detachment

$$
=\frac{\text { wash }(\mathrm{cpm}) \times 100}{\text { supernatant }(\mathrm{cpm})+\text { wash }(\mathrm{cpm})+\text { lysate }(\mathrm{cpm})}
$$

Cell detachment represents the cells that were viable but were unable to maintain adhesion to the underlying matrix when exposed to the sheer stress of washing. Cell detachment is frequently used as an index of cell dysfunction (23-25)

Statistics. All values are presented as means \pm SEM. The EDTA clearance data over time and treatment (sham and I/R groups) were analyzed with repeated measures ANOVA followed by appropriate posthoc comparisons.

\section{Results}

The effects of I/R on jejunal clearance of ${ }^{51} \mathrm{Cr}$-EDTA are shown in Fig. 1. In control (sham-operated) animals, reperfusion of the jejunal segment resulted in an increase in EDTA clearance that returned to control levels within $1 \mathrm{~h}$. In animals that had been exposed to a previous ( $24 \mathrm{~h}$ earlier) I/R insult, there was very little effect on jejunal EDTA clearance upon reperfusion. Morphological analyses (Fig. 2) confirmed that the mucosal epithelium was injured upon reperfusion in the sham-operated rats $(46.6 \pm 1.3 \%$ of the villi had a discontinuous epithelial lining). In general, the injury was characterized by sheets of epithelium detaching from the lamina propria. Reperfusion-induced epithelial injury was dramatically reduced by a previous exposure of the intestine to an $I / R$ insult $(13.3 \pm 2.7 \%$ of the villi had a discontinuous epithelium). Taken together, these findings indicate that I/R-induced injury to the small intestine can be ameliorated by a previous I/R insult (i.e., I/R tolerance can be induced in the small intestine).

When the interval between I/R insults was reduced to $1 \mathrm{~h}$, I/ $R$ tolerance did not develop. As shown in Fig. 3, it required $\sim 1 \mathrm{~h}$ for the membrane defect (i.e., increase in EDTA clearance) to resolve itself after the initial I/R insult. The subsequent I/R-induced increase in EDTA clearance was no different from that observed in the animals not exposed to the initial I/R insult. When the interval between I/R insults was extended to $72 \mathrm{~h}$, I/R tolerance could no longer be demonstrated. As shown in Fig. 4, the I/R-induced increases in EDTA clearance in the sham-operated animals and in animals exposed to a previous ( $72 \mathrm{~h}$ earlier) I/R insult were similar.

Biochemical analyses of the antioxidant status of the jejunal mucosa at 1, 24, and $72 \mathrm{~h}$ after the initial I/R insult are shown in Table I. At $24 \mathrm{~h}$ after the initial insult, mucosal GSHPX and catalase activities were increased, while SOD activity was unchanged when compared to sham-operated controls. Mucosal levels of GSH were also increased at $24 \mathrm{~h}$ after the initial I/R insult. HPLC analysis confirmed that $24 \mathrm{~h}$ after the insult, $97 \%$ of the total mucosal thiol content was GSH in both sham and I/R-treated animals. At 1 and $72 \mathrm{~h}$ after the initial insult, there were no significant changes in any of the measured antioxidants, as compared to the sham-operated controls. These findings indicate that the development of I/R tolerance in the small intestine is associated with an increase in the mucosal antioxidant status.

Based on the above findings, we tested the hypothesis that I/R tolerance was specific for oxidant-mediated injury. As shown in Fig. $5 A$, perfusion of the jejunal lumen with $\mathrm{H}_{2} \mathrm{O}_{2}$ produced an increase in EDTA clearance in the sham-operated animals, but not in the animals exposed to a previous ( $24 \mathrm{~h}$ earlier) I/R insult. By contrast, perfusion of the lumen with hydrochloric acid produced similar increases in EDTA clearances in the sham-operated animals and in animals exposed to 

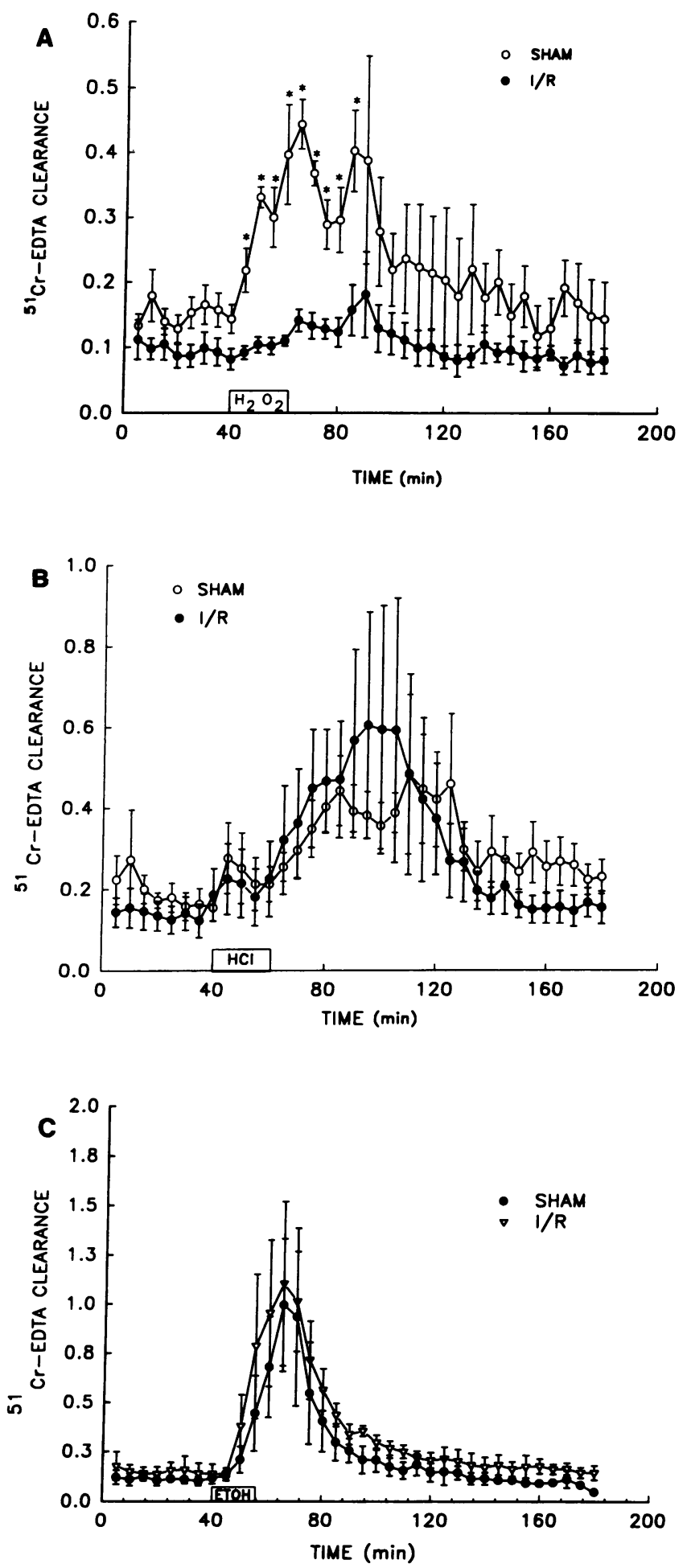

Figure 5. The effects of luminal perfusion with $5 \mathrm{mM} \mathrm{H}_{2} \mathrm{O}_{2}(A), \mathrm{HCl}$ $(B)$, or ethanol $(C)$ on ${ }^{51} \mathrm{Cr}$-EDTA clearance across the jejunal mucosal epithelium in animals whose SMA was occluded for $15 \mathrm{~min}(I / R)$ and animals whose SMA was merely massaged (SHAM) $24 \mathrm{~h}$ earlier. All values $\left(\mathrm{ml} \cdot \mathrm{min}^{-1} \cdot 100 \mathrm{~g}^{-1}\right)$ are expressed as the mean \pm SEM from three to five animals in each group. As the omnibus ANOVA revealed significant interaction between time and treatment (sham vs I/R groups) in the experiments with $\mathrm{H}_{2} \mathrm{O}_{2}$ posthoc comparisons (Duncan's test) for each time point were performed. ${ }^{*} P<0.05$ compared to corresponding time point in $I / R$ group. a previous I/R episode (Fig. $5 \mathrm{~B}$ ). Similarly, perfusion of the lumen with ethanol produced similar increases in EDTA clearances in sham-operated and I/R-treated animals (Fig. $5 C$ ). Taken together, these findings indicate that a previous I/R insult to the small intestine renders the intestine less susceptible to oxidant-induced injury, but does not affect the susceptibility of the intestine to acid- or ethanol-induced injury.

To assess whether the epithelial cells lining the villi actively participate in the development of oxidant tolerance, they were separated from the lamina propria $24 \mathrm{~h}$ after the initial I/R insult, and their antioxidant status was assessed. As shown in Table II, there were no significant changes in any of the measured antioxidants, compared with the sham-operated controls. By contrast, $24 \mathrm{~h}$ after the initial I/R insult, the activities of SOD, catalase, and GSHPX in the lamina propria were significantly increased compared with sham-operated controls. These observations suggest that epithelial cells do not participate in the development of oxidant tolerance in the small intestine.

In another series of experiments, epithelial cells were removed from the villus tips $24 \mathrm{~h}$ after the initial insult, and their sensitivity to $\mathrm{H}_{2} \mathrm{O}_{2}$ was assessed by $\mathrm{LDH}$ release. As shown in Table III, the epithelial cells obtained from previously insulted intestines were just as insensitive to $\mathrm{H}_{2} \mathrm{O}_{2}$ as those obtained from sham-operated controls.

In vitro studies were performed to determine whether oxidant tolerance could be induced in an epithelial cell line, Caco2. As shown in Fig. 6, exposure of the monolayers to $\mathrm{H}_{2} \mathrm{O}_{2}$ for $4 \mathrm{~h}$ did not produce any detectable injury to the monolayers until concentrations of $\sim 5 \mathrm{mM}$ were used. The injury was nonlytic since there was no increase in chromate release; only cell detachment was observed. Pretreatment of the monolayers with 400-1,600 $\mu \mathrm{M} \mathrm{H}_{2} \mathrm{O}_{2} 24 \mathrm{~h}$ earlier did not alter the degree of cell detachment induced by $\mathrm{H}_{2} \mathrm{O}_{2}$.

\section{Discussion}

There is a growing body of evidence indicating that a brief I/ $\mathrm{R}$ episode can render tissue more resistant to injury from a subsequent I/R challenge $(6,7,19,26-32)$. Collectively, the available evidence indicates that the development of I/R tolerance can be subdivided into two distinctly different phenomena, based on the time course and mechanisms involved in the protection. In the heart, the protective effect of a previous $I / R$ episode is apparent within minutes after the initial insult and persists for $\leq 1-2$ hours, after which the susceptibility of the tissue to I/R injury returns to normal $(9,26-32)$. This phenomenon, referred to as "preconditioning," is independent of protein synthesis (32), and it is not associated with alterations in the activity of endogenous antioxidant enzymes (31). By contrast, studies in the brain and kidney indicate that the protective effect of a previous $I / R$ insult requires days to develop $(6,7)$. For example, in the kidney, it requires up to $6 \mathrm{~d}$ after the initial $\mathrm{I} / \mathrm{R}$ insult before the tissue becomes less susceptible to a second I/R challenge (6). The development of this I/R tolerance is associated with an enhanced antioxidant status of the tissue. The results of the present study indicate that the development of I/R tolerance in the small intestine is analogous to the latter phenomenon. In the small intestine, I/R tolerance is present at $24 \mathrm{~h}$, but not at $1 \mathrm{~h}$, after the initial I/R insult. We also show that the development of I/R tolerance in the intestine is associated with an improved antioxidant status of the mucosa. 
Table II. Localization of the Enhanced Antioxidant Status within the Jejunal Mucosa $24 h$ after an I/R Insult

\begin{tabular}{|c|c|c|c|c|c|c|c|c|}
\hline & \multicolumn{2}{|c|}{ Villus tip epithelium } & \multicolumn{2}{|c|}{ Mid-villus epithelium } & \multicolumn{2}{|c|}{ Crypt epithelium } & \multicolumn{2}{|c|}{ Lamina propria } \\
\hline & SHAM & ISCHEMIC & SHAM & IR & SHAM & IR & SHAM & IR \\
\hline SOD & $4.3 \pm 0.5$ & $4.5 \pm 0.3$ & $4.1 \pm 0.3$ & $4.4 \pm 0.6$ & $3.9 \pm 0.2$ & $4.0 \pm 0.5$ & $4.3 \pm 0.1$ & $6.1 \pm 0.2 *$ \\
\hline CAT & $5.5 \pm 0.9$ & $6.9 \pm 0.1$ & $5.0 \pm 0.9$ & $6.2 \pm 1.0$ & $4.1 \pm 0.6$ & $4.8 \pm 0.7$ & $3.6 \pm 0.1$ & $5.1 \pm 0.1^{*}$ \\
\hline GSHPX & $29 \pm 6$ & $27 \pm 4$ & $32 \pm 6$ & $27 \pm 6$ & $32 \pm 8$ & $30 \pm 6$ & $54 \pm 2$ & $60 \pm 2 *$ \\
\hline GSH & $6.7 \pm 0.3$ & $7.5 \pm 0.5$ & $6.5 \pm 1.2$ & $7.2 \pm 0.7$ & $4.7 \pm 0.7$ & $5.1 \pm 0.9$ & $5.9 \pm 0.6$ & $6.5 \pm 0.6$ \\
\hline
\end{tabular}

$I / R$, animals whose superior mesenteric artery was occluded for $15 \mathrm{~min}$ at $24 \mathrm{~h}$ before biopsy; SHAM, animals whose superior mesenteric artery was only massaged at $24 \mathrm{~h}$ before biopsy. Enzyme activities are expressed in milliunits per milligram, while GSH content is expressed in micrograms per milligram of protein. Values represent mean \pm SEM of assays on samples obtained from six to eight rats. $* P<0.05$ compared to SHAM. (Student's $t$ test).

It is generally believed that reperfusion of ischemic tissue results in increased production of ROM. The ROM generated overwhelm the endogenous antioxidants (both enzymatic and nonenzymatic) and produce tissue injury $(1,2,4)$. Our observations would indicate that these ROM may also increase tissue levels of antioxidant enzymes via substrate induction and, thereby, confer protection against a subsequent oxidant challenge (i.e., I/R insult). In support of this possibility are the observations that a previous $I / R$ insult offered protection against $\mathrm{H}_{2} \mathrm{O}_{2}$-induced, but not $\mathrm{HCl}$-or ethanol-induced, mucosal injury. Previous studies (6) have also shown that a mild I/R insult to the kidney increases the activities of endogenous antioxidant enzymes and renders the kidney less susceptible to a subsequent I/R insult or $\mathrm{H}_{2} \mathrm{O}_{2}$ challenge. Taken together, these findings indicate that a mild $I / R$ insult can lead to development of oxidant tolerance by enhancing the antioxidant status of the tissue.

The present study represents the first attempt to demonstrate that oxidant tolerance can be induced in a labile organ system (i.e., the small intestine). In the small intestine, the entire epithelium is replaced every $2-3 \mathrm{~d}$ by migration of cells up the villi and subsequent loss into the lumen (18). Interestingly, I/ $\mathrm{R}$ tolerance disappears along with a return to a normal mucosal antioxidant status within $3 \mathrm{~d}$ after the initial I/R insult. These findings suggest that an adaptive response by the epithelial cells present at the time of the initial insult is necessary for oxidant tolerance to develop. Once these cells have been replaced by a new population of cells not exposed to I/R insults, the mucosa is no longer resistant to $I / R$ challenges. However, further experimentation to test this hypothesis indicated that epithelial cells

Table III. Effect of $5 \mathrm{mM} \mathrm{H}_{2} \mathrm{O}_{2}$ on $\mathrm{LDH}$ Release from Epithelial Cells Isolated from Rat Jejunal Villi $24 \mathrm{~h}$ after an I/R Insult

\begin{tabular}{cccccc}
\hline & \multicolumn{2}{c}{ SHAM } & & \multicolumn{2}{c}{ I/R } \\
\cline { 2 - 3 } \cline { 5 - 6 } $\begin{array}{c}\text { Duration } \\
\text { of exposure }\end{array}$ & \multicolumn{1}{c}{$\mathrm{PBS}$} & \multicolumn{1}{c}{$\mathrm{H}_{2} \mathrm{O}_{2}$} & & PBS & \multicolumn{1}{c}{$\mathrm{H}_{2} \mathrm{O}_{2}$} \\
\hline $10 \mathrm{~min}$ & $24.5 \pm 3.5$ & $25.1 \pm 3.2$ & & $20.3 \pm 2.4$ & $26.3 \pm 2.3$ \\
$20 \mathrm{~min}$ & $43.3 \pm 11.2$ & $39.0 \pm 12.7$ & & $31.6 \pm 6.9$ & $40.9 \pm 14.1$
\end{tabular}

$I / R$, animals whose superior mesenteric artery was occluded for $15 \mathrm{~min}$ and released; SHAM, animals whose superior mesenteric artery was only massaged. Values represent mean \pm SEM of percent of total releasable LDH from Triton-treated epithelial cells isolated from four to six rats. do not play an active role in the development of oxidant tolerance in the intestinal mucosa.

When the epithelial cells were separated from the lamina propria $24 \mathrm{~h}$ after the initial $\mathrm{I} / \mathrm{R}$ insult and their antioxidant status was assessed, it was found to be unchanged. However, the antioxidant status of the lamina propria was enhanced $24 \mathrm{~h}$ after the initial I/R insult. Catalase and GSHPX activities, as well as GSH, were increased in both whole mucosal scrapings and isolated lamina propria. By contrast, SOD activity was increased in the lamina propria, but not whole mucosa, $24 \mathrm{~h}$ after the initial insult. The reasons for these differences are not readily apparent, but may reflect animal and seasonal variations in basal antioxidant status and/or responsiveness to an I/R insult. Despite the latter discrepancies, the data collectively indicate that the increase in the antioxidant status of the mucosa observed $24 \mathrm{~h}$ after the initial I/R insult is a result of adaptational changes in the lamina propria, rather than in the epithelium.

Further evidence negating an active role for the epithelium in the development of oxidant tolerance was provided by experiments performed with isolated epithelial cells. Intestinal epithelial cells removed from the villus tips $24 \mathrm{~h}$ after the initial I/R insult were just as insensitive to $\mathrm{H}_{2} \mathrm{O}_{2}$ as epithelial cells obtained from sham-operated controls. This observation indicates that, after the initial I/R insult, the epithelial cells lining the villus did not mount an adaptive response that would render them more resistant to the cytotoxic effects of $\mathrm{H}_{2} \mathrm{O}_{2}$. Furthermore, pretreatment of Caco- 2 cell monolayers with $\mathrm{H}_{2} \mathrm{O}_{2}$ did not render them less sensitive to a $\mathrm{H}_{2} \mathrm{O}_{2}$ challenge $24 \mathrm{~h}$ later. Taken together, these findings indicate that the epithelium plays only a passive role in the development of oxidant tolerance in the intestinal mucosa.

The role of the epithelium in oxidant-induced injury to the mucosal barrier may also be passive. In vivo studies indicated that within 10-20 min of luminal perfusion with $5 \mathrm{mM} \mathrm{H}_{2} \mathrm{O}_{2}$, mucosal permeability to EDTA increased three- to fourfold. However, exposure of epithelial cells harvested from the villus tips to $5 \mathrm{mM} \mathrm{H}_{2} \mathrm{O}_{2}$ for the same period of time did not result in cell lysis as evidenced by LDH release (Table III). Caco-2 cells were also resistant to $\mathrm{H}_{2} \mathrm{O}_{2}$, with monolayer disruption occurring at high concentrations (6-7 $\mathrm{mM}$ ) and prolonged exposure $(4 \mathrm{~h})$. Even then, the injury was primarily nonlytic, i.e., the cells were simply more readily detached by imposing a shear stress (wash) across the monolayer (Fig. 6). Taken to- 

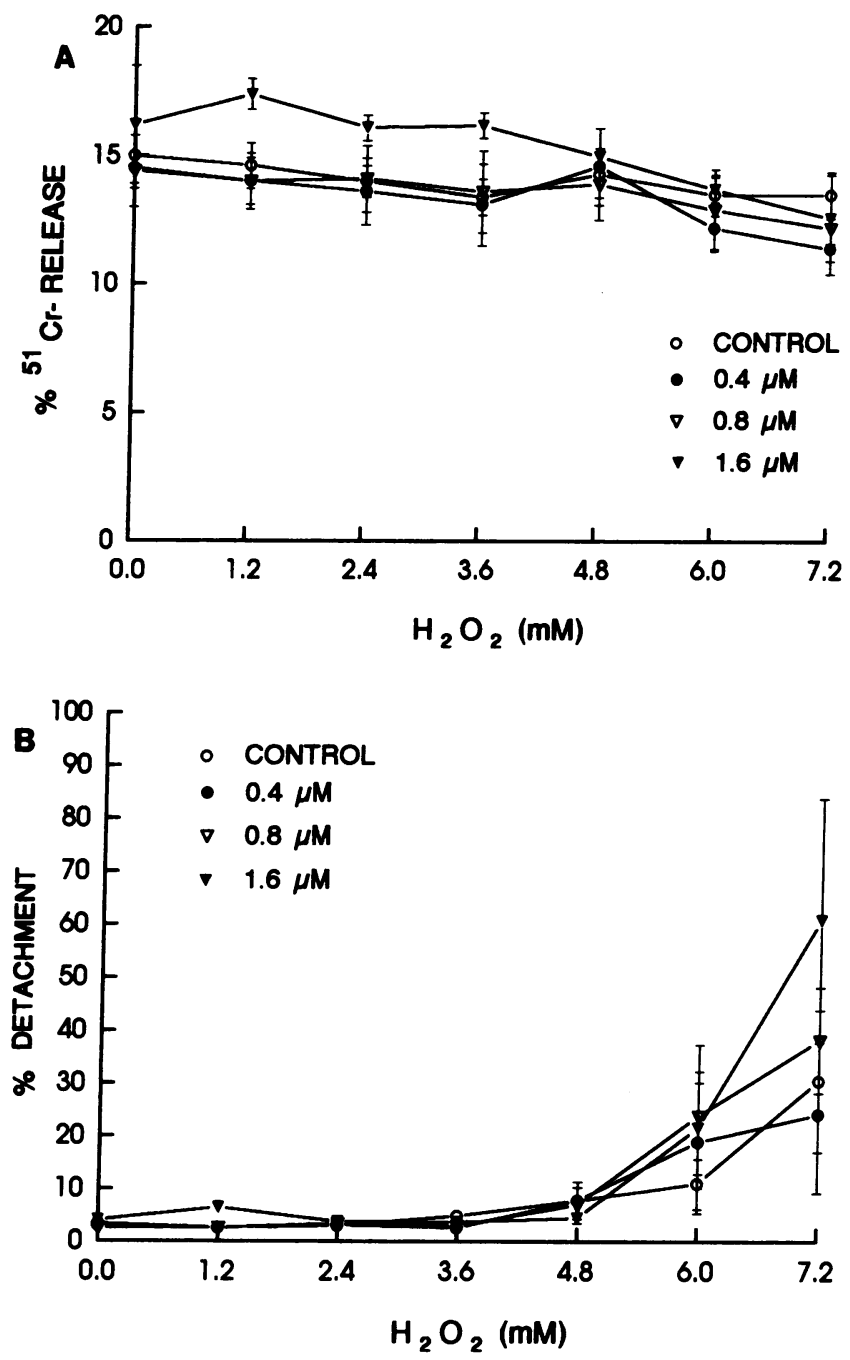

Figure 6. $\mathrm{H}_{2} \mathrm{O}_{2}$-induced disruption of Caco-2 cell monolayers in untreated and $\mathrm{H}_{2} \mathrm{O}_{2}$-pretreated monolayers. Caco-2 monolayers were pretreated with 400,800 , or $1,600 \mu \mathrm{m} \mathrm{H}_{2} \mathrm{O}_{2} 24 \mathrm{~h}$ before assessment of $\mathrm{H}_{2} \mathrm{O}_{2}$-induced ${ }^{51} \mathrm{Cr}$-release $(A)$ and epithelial cell detachment $(B)$.

gether, these findings suggest that, in vivo, $\mathrm{H}_{2} \mathrm{O}_{2}$ may be altering epithelial membrane permeability indirectly by an action on resident cells or structural elements (e.g., basement membrane) within the lamina propria, which ultimately leads to cell detachment. However, it is also possible that $\mathrm{H}_{2} \mathrm{O}_{2}$-induced cell detachment may be caused by induction of epithelial cell apoptosis.

The identity of the cell type(s) in the lamina propria that respond to an I/R insult by enhancing their antioxidant status is not clear. One likely candidate is the endothelium. Endothelial cells in culture can develop oxidant tolerance in response to an oxidant stress (33). Exposure of pulmonary artery endothelial cells to nontoxic levels of $\mathrm{H}_{2} \mathrm{O}_{2}$ for 18-24 h increased (a) their endogenous activities of SOD, catalase, and GSHPX; and (b) their resistance to $\mathrm{H}_{2} \mathrm{O}_{2}$-induced cytotoxicity. In vivo studies in the kidney indicate that an $I / R$ insult results in an increased tolerance to a second $\mathrm{I} / \mathrm{R}$ insult or $\mathrm{H}_{2} \mathrm{O}_{2}$ challenge $6 \mathrm{~d}$ later (6). The development of this oxidant tolerance is associated with increased activity of SOD, catalase, and GSHPX in renal glomeruli, a segment of the nephron consisting primarily of endothelium. Although endothelial cells can mount an adaptive response to an $I / R$ insult or oxidant challenge, we cannot exclude other resident cell populations in the lamina propria from contributing to the development of oxidant tolerance in the intestine. Further studies are warranted to definitively identify the cell types in the lamina propria that increase their antioxidant status in response to an $I / R$ insult, and how this adaptive response renders the epithelium more resistant to an oxidant challenge.

In summary, the results of the present study indicate that oxidant tolerance can be induced in a labile organ system, the small intestinal mucosa. $24 \mathrm{~h}$ after an initial ischemia insult, the epithelial barrier is less susceptible to injury induced by a subsequent I/R episode or luminal perfusion with $\mathrm{H}_{2} \mathrm{O}_{2}$. The development of this oxidant tolerance is associated with an enhanced antioxidant status of the mucosa, indicating that induction of antioxidant enzymes is an important mechanism in this adaptational response. However, we cannot exclude the possibility that other factors, such as induction of heat shock proteins, may also contribute to the development of oxidant tolerance (33).

\section{Acknowledgments}

The authors thank D. Neil Granger and Gregory B. Bulkley for helpful discussions. We also thank Dr. Indrani Nandy of Biometry and Academic Computing at LSU for statistical analyses.

D. L. Osborne was supported by a fellowship from the Louisiana affiliate of the American Heart Association. T. Y. Aw is supported by an Established Investigator Award from the American Heart Association. This work was supported by National Institutes of Health grants HL-48855, DK-41399, DK-44510, and DK-43785.

\section{References}

1. Sies, H. 1991. Oxidative stress: from basic research to clinical application. Am. J. Med. 91:3C,31S-38S.

2. Reilly, P. M., H. J. Schiller, and G. B. Bulkley. 1991. Pharmacologic approach to tissue injury mediated by free radicals and other reactive oxygen metabolites. Am. J. Surg. 161:488-503.

3. Korthuis, R. J., and D. N. Granger. 1993. Reactive oxygen metabolites, neutrophils, and the pathogenesis of ischemic-tissue/reperfusion. Clin. Cardiol. 16(Suppl. I):I19-I26.

4. Granger, D. N. 1988. Role of xanthine oxidase and granulocytes in ischemia/reperfusion injury. Am. J. Physiol. 255:H1269-1275.

5. Bensard, D. D., J. M. Brown, B. O. Anderson, A. Banerjee, P. F. Shanley, M. A. Grosso, G. J. R. Whitman, and A. H. Harken. 1990. Induction of endogenous tissue antioxidant enzyme activity attenuates myocardial reperfusion injury. $J$. Surg. Res. 49:126-131.

6. Yoshioka, T., T. Bills, T. Moore-Jarrett, H. L. Greene, I. M. Burr, and I. Ichikawa. 1990. Role of intrinsic antioxidant enzymes in renal oxidant injury. Kidney Int. 38:282-288.

7. Kitagawa, K., M. Matsumoto, K. Kuwabara, M. Tagaya, T. Ohtsuki, R. Hata, H. Ueda, N. Handa, K. Kimura, and T. Kamada. 1991. 'Ischemic tolerance' phenomenon detected in various brain regions. Brain Res. 561:203-211.

8. Cepinskas, G., R. D. Specian, and P. R. Kvietys. 1993. Adaptive cytoprotection in the small intestine: role of mucus. Am. J. Physiol. 264:G921-G927.

9. Kvietys, P. R., R. D. Specian, M. B. Grisham, and P. Tso. 1991. Jejuna mucosal injury and restitution: role of hydrolytic products of food digestion. Am. J. Physiol. 261:G384-G391.

10. Nylander, O., P. R. Kvietys, and D. N. Granger. 1989. Effects of hydrochloric acid on duodenal and jejunal mucosal permeability in the rat. Am. J. Physiol. 257:G653-G660.

11. Crissinger, K. D., P. R. Kvietys, and D. N. Granger. 1990. Pathophysiology of gastrointestinal mucosal permeability. J. Intern. Med. 228(Suppl. 732):145154.

12. Weiser, M. M. 1973. Intestinal epithelial cell surface membrane glycoprotein synthesis. I. An indicator of cellular differentiation. J. Biol. Chem. 248:25362541 . 
13. Crapo, J. D., J. M. McCord, and I. Fridovich. 1978. Preparation and assay of superoxide dismutases. Meth. Enzymology. 53:382-387.

14. Aebi, H. 1984. Catalase in vitro. Methods Enzymol 105:121-126.

15. Tappel, A. L. 1978. Gluthathione peroxide and hydroperoxidase. Methods Enzymol. 52:506-513.

16. Owens, C. W. I., and R. V. Belcher. 1965. A colorimetric micro-method for determination of glutathione. Biochem. J. 94:705-711.

17. Bradford, M. A. 1976. A rapid and sensitive method for the quantitation of microgram quantities of protein utilizing the principle of protein-dye binding. Anal. Biochem. 72:248-254.

18. Messier, B., and C. P. Leblond. 1960. Cell proliferation and migration as revealed by radioautography after injection of thymidine- $\mathrm{H}^{3}$ into male rats and mice. Am. J. Anat. 106:247-265.

19. Walker, D. M., and D. M. Yellon. 1992. Ischaemic preconditioning: from mechanisms to exploitation. Cardiovasc. Res. 26:734-739.

20. Bergmeyer, H. U., E. Bent, and B. Hess. 1965. Lactate Dehydrogenase. In Methods of Enzymatic Analysis. H. U. Bergmeyer, editor. Academic Press, NY. pp. 736-741.

21. Kumagai, J., R. Jain, and L. R. Johnson. 1989. Characteristics of spermidine uptake by isolated rat enterocytes. Am. J. Physiol. 256:G905-G910.

22. Zweibaum, A., M. Laburthe, E. Grasset, and D. Louvard. 1991. Use of cultured cell lines in studies of intestinal cell differentiation and function. In Handbook of Physiology. The Gastrointestinal System. Intestinal Absorption and Secretion. Vol. IV. Bethesda, MD. pp. 223-255.

23. Yoshida, N., T. Takemura, D. N. Granger, D. C. Anderson, R. E. Wolf, L. V. McIntire, and P. R. Kvietys. 1993. Molecular determinants of aspirininduced neutrophil adherence to endothelial cells. Gastroenterology 105:715724.
24. Moldow, C. F., and H. S. Jacob. 1984. Endothelial culture, neutrophil or enzymic generation of free radicals: in vitro methods for the study of endothelial injury. Methods Enzymol. 105:378-385

25. Harlan, J. M., P. D. Killen, L. A. Harker, and G. E. Striker. 1981. Neutrophil-mediated endothelial injury in vitro. Mechanisms of cell detachment. J. Clin. Invest. 68:1394-1403.

26. Reimer, K. A., C. E. Murry, and R. B. Jennings. 1990. Cardiac adaptation to ischemia. Ischemic preconditioning increases myocardial tolerance to subse quent ischemic episodes. Circulation. 82:2266-2268.

27. Mullane, K. 1992. Myocardial preconditioning. Part of the adenosine revival. Circulation. 85:845-847.

28. Murry, C. E., R. B. Jennings, and K. A. Reimer. 1991. New insights into potential mechanisms of ischemic preconditioning. Circulation. 84:442-445.

29. Li, G. C., J. A. Vasquez, K. P. Gallagher, and B. R. Lucchesi. 1990. Myocardial protection with preconditioning. Circulation. 82:609-619.

30. Liu, Y., and J. M. Downey. 1992. Ischemic preconditioning protects against infarction in rat heart. Am. J. Physiol. 263:H1107-H1112.

31. Turrens, J. F., J. Thornton, M. L. Barnard, S. Snyder, G. Liu, and J. M. Downey. 1992. Protection from reperfusion injury by preconditioning hearts does not involve increased antioxidant defenses. Am. J. Physiol. 262:H585-H589.

32. Thornton, J., S. Striplin, G. S. Liu, A. Swafford, A. W. F. Stanley, D. M. Van Winkle, and J. M. Downey. 1990. Inhibition of protein synthesis does not block myocardial protection afforded by preconditioning. Am. J. Physiol. 259:H1822-H1825.

33. Lu, D., N. Maulik, I. I. Moraru, D. L. Kreutzer, and D. K. Das. 1993 Molecular adaptation of vascular endothelial cells to oxidative stress. Am. J. Physiol. 264:C715-C722. 